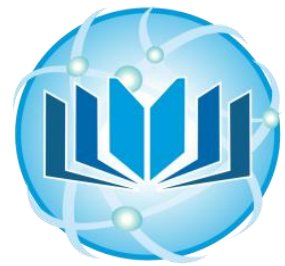

https://doi.org/10.33805/2576-8484.132

Volume 2 Issue 1 | PDF 132 | Pages 13

Edelweiss Applied Science

EDELWEISS PUBLICATIDNS

IPEN ACCESS

and Technology

\title{
Effect of Mentoring on Military Personnel Retention
}

\section{Shewakena Aman}

Affiliation: Adama Science and Technology University, Adama Ethiopia

"Corresponding author: Shewakena Aman, Adama Science and Technology University, Adama Ethiopia, E-mail: shewafen@gmail.com

Citation: Aman S. Effect of Mentoring on Military Personnel Retention (2018) Edelweiss Appli Sci Tech 2: 156-168

Received: Dec 26, 2017

Accepted: Feb 09, 2018

Published: Feb 15, 2018

Copyright: $\odot 2018$ Aman S. This is an open-access article distributed under the terms of the Creative Commons Attribution License, which permits unrestricted use, distribution, and reproduction in any medium, provided the original author and source are credited.

\begin{abstract}
Retention of human capital is an asset to any organization and as a result, mentoring and retention has become an issue of importance for any organization. This study, therefore, analyzed the effect of mentoring on military personnel retention in Ethiopian military academies. Methodologically, the research approach is quantitative and the design was descriptive and explanatory type of research, where the population of the study is the protégés of military academies in Ethiopia. The sampling method is probability and specifically stratified random sampling. The data were collected using structured questionnaires. The researcher used both descriptive and inferential statistics. The result of person correlation revealed that mentoring has positive and significant relationship with personnel retention in military academies. Furthermore, the results of regression analysis indicated that mentoring has positive and significant effect on personnel retention in the studied academies. It was found that psychological mentoring has higher effect on military personnel retention than career mentoring and role modeling. Findings of this study shows that providing mentoring for military personnel is positively and significantly related to higher psychological readiness, career development, and personnel retention. Military academies are better to emphasize on psychological mentoring to enhance the retention of military personnel.
\end{abstract}

Keywords: Career mentoring; Psychological mentoring; Role modeling; Personnel retention.

\section{Introduction}

\section{Background of the Study}

Human resource is valuable and serves as the backbone of organizations in the world. Employees are key resources that can be strategically placed for an organization to attain competitive advantage It is obvious that developing and retaining the capabilities of employee is an important part of any institution. Organizations can no longer expect to be competitive unless they inspire, mentor and make them learn continuously. Thus this study aims to assess the effects of mentoring on military personnel retention in Ethiopian military context.

Vijayalaxmi (2012) stated that mentoring is one of the most researched topics in the world. It has been used by various organizations and educational institutions for career development and the development of specific skills for employees to make them more efficient. Educational institutions are implementing mentoring programs to groom the students and develop them in a more holistic manner. The business world adopted the program in order to encourage the employees to take a more proactive part in the career planning and help new entrant to acclimatize him or herself to the new work environment.

According to Jubilee et al. (2014), mentoring is defined as the process of developing and maintaining intensive, lasting and sustainable developmental relationships between senior and junior persons. This relationship has been shown to involve career mentoring (e.g. coaching, protection, challenging assignments and exposure) and psychological mentoring (e.g. friendship, counseling and acceptance) and role-modeling functions for the protégés.
Chiboiwa et al. (2010) specified that retention refers to the maintenance of employment status by an organization for a considerable long period of time. The main purpose of retention is to prevent competent employees from leaving the organization as this could have adverse effects on productivity and service delivery. Besides, Christopher et al. (2012) demonstrated that mentoring fosters employees retention in part because the emotional bond established between a mentor and a protégés may contribute to higher levels of employee retention.

So that, Mentoring operate through a dual pathways to influence military personnel commitment by assisting in the transfer of professional knowledge while simultaneously developing the highquality interpersonal relationships that strengthen a protégés commitment and retention to the organization.

Further, Alethea \& Ridwanah (2013) reveled that mentoring has positive effects for mentees, mentors, and for organizations. Mentees experience career advancement and increased confidence in the workplace. Mentors experience personal satisfaction, collegiality, networking, career enhancement and organizations improved efficiency, recruiting, employee socialization, and commitment Therefore, any organization to be effective there is a need of timely assesses mentoring effect that promote mentoring functions, while simultaneously fostering a commitment to the organization that enhances employee retention.

Alexis and Judith, (2013) has concluded that mentoring in the organization increases employee commitment by offering space for dialogue and regular feedback. As a result, mentoring creates clarity on 
various issues such as the importance of ones role, job expectations and career advancement. And also enhances employees communications and develops the quality of working relationships with peers, leaders and subordinates. These factors contribute to improving team spirit and ultimately leading to an increase in satisfaction, efficiency and personnel commitment.

According to Ethiopian Army Human resource Field Manual (2011), military units have also been engaged in mentoring relationship for the purpose of knowledge and experience sharing, talent development, improvement of the personnels abilities, efficiency and to enhance personnel retention, core value assimilation and diversity enhancement As far as the researcher observation is concerned military units carry out mentoring practice without evaluating or measuring its effect. And unfortunately the researcher could not access any research conducted on the effect of mentoring on personnel retention in the context of Ethiopian military units.

Therefore, research works need not to be saturated in areas where there are many duties as far as there are no special and justifiable reasons to do so. These initiate the interest on the researcher to study the effect of mentoring on military academies.

In line of this insight the researcher will assess the effect of mentoring functions on personnel retention in Ethiopian military academies.

Military Academies are colleges and training centers which are found in Ethiopian defense force training main department which were established between 2000 -2004. Major general Hayelom Araya military academy is located at Holeta town west of Addiss Abbaba, Command and Staff College is found in Addis Ababa. The mission of the military academies were to produce well qualified and capable subunits ,tactical, operational and strategic level leaders, for all defense forces units by providing quality education and training and the academies have 700 military personnel and civil employees.

All the officers who are found in the academies served as a mentor and their followers are the protégé. In the military academies, mentoring programs are segments of human capital development that have consistently and continuously been implemented since the inauguration of the academies. The military academies used mentoring practice to transfer knowledge, skill, experience and behavior from senior officer to subordinates, to retain personnel, assimilation of core value and diversity enhancement and it is long time practice in the military academies (Ethiopian Army Human resource Field Manual, 2011).

\section{Statement of the Problem}

Mentoring has become globally recognized for its effect in leveraging personal and organizational development. It can thus be a powerful tool if studied properly to encourage development and commitment on all levels of employee (François, et al., 2014). According to Cheng et al. (2014), the fundamental purposes of mentoring are to help attract, motivate, develop and retain profita-ble talent while increasing efficiency. It is goal-oriented, promotes professional and personal growth amongst participants and it facilitates the sharing of knowledge, expertise, skills, insights and experiences through dialog and collaborative learning. On the other hand, Chronus (2014) mentioned that successful companies whether large or small, use mentoring to tackle complex human resource challenges such as increasing employee retention and improving workforce efficiency. In the same fashion, Ethiopian military academies have also been engaged in mentoring practice for the purpose of knowledge and experience sharing, improvement of career development, enhancement of personnel retention, psychological readiness and diversity enhancement (Ethiopian Army Regiment Field Manual, 2011). However there is no study shows how mentoring is effective in the military academies. David and John, (2014) conducted research on US Army officers; found that serving under a high-performing mentor significantly increases the likelihood that a junior officer protégé' will be promoted early to the next rank. The magnitude of the increase in promotion rates is large, representing a $29 \%$ increase in the average early promotion rate. Thus, early promotion in the army increases commitment and personnel retention. In addition, Kenneth (2013), a study on the effect of mentoring and turnover intentions in the united states of American air force and found that those who receive mentoring from a senior member of an organization would tend to experienced higher levels of organizational commitment and lower level of turnover intention.

Further, Carla (2011) conducted a study on the effects of mentoring on job satisfaction among military academicians and the findings suggest that faculty members with mentors have higher levels of job satisfaction than faculty members without mentors. Moreover, another study has been conducted by Angela (2013) on the relationship between mentoring, job satisfaction and the retention of special education teachers in Georgia and the finding indicated that mentoring positively affects job satisfaction and retention of teachers. In addition, Brad, Johnson and Gene, (2011) conducted research on formal mentoring in the USA military and the findings conclude that formal mentoring brings significant benefits to all those involved in the mentoring relationship, including the organization. The mentee gains knowledge and wisdom about the organization knowledge, learns faster, has increased self-confidence, career motivation, commitment and retention. Besides, Ayşe et al. (2013) conducted a study on effect of mentoring on organizational commitment, and job satisfaction in Turkey. The result indicated that mentoring has a positive effect on employee commitment and job satisfaction.

Another study has been conducted by Catherine and Mike, (2014) on the role of mentoring programs on the employee performance in public universities in Kenya and the study established that mentorship programs play an important role in employee performance and enhanced through knowledge transfer and career development. Lastly, Knowles and Parsons, (2010) argued that mentoring is generally accredited in a positive way and perceived as decent, however there was no evidence on the effect of mentoring on employees behavior and attendance.

The above studies were conducted with in a context of other countries. And unfortunately the researcher could not access any research which is conducted in Ethiopia relating mentoring and retention in general and particularly the mentoring functions (career mentoring, psychological mentoring and role modeling) and personnel retention. So far the conducted studies concentrated their scope on the effect of mentoring on organizational commitment, job satisfaction, benefit, types, role, student and teacher retention in academic institutions, success of mentoring program and little studies conducted on the effect of mentoring on army turnover in other countries and economic regions. Therefore, the lack of theoretical and empirical evidence in our country was what initiated the researcher to undertake this research.

\section{Objectives of the Study}

General objective: The general objective of this study was to examine the effect of mentoring on military personnel retention on military academies in Ethiopia.

Specific objectives: The specific objectives of the study were:

1. To examine the relationship between mentoring and personnel retention in military academies.

2. To evaluate the effect of career mentoring on personnel retention in military academies

3. To analyze the effect of psychological mentoring on personnel retention in military academies.

4. To examine the effect of role modeling on personnel retention in military academies.

\section{Hypotheses of the Study}

In order to successfully attain the objectives of this study the following hypotheses were considered. 


\section{Hypothesis 1}

H0: Mentoring does not correlate with retention in Ethiopia Military academies

Hypothesis 2

H0: Career mentoring does not influence retention in Ethiopian Military academies

Hypothesis 3

H0: Psychological mentoring does not influence retention in Ethiopian military academies

Hypothesis 4

H0: Role modeling does not influence retention in Ethiopian Military academies

Delimitation of the study: This study was delimited to the effects of mentoring on military personnel retention in military academies it was delimited in identifying what are the effects of mentoring function in personnel retention and the study covered 3 military academies. The researcher selected these three military academies because of the mentoring practice which is continuously implemented in the military academies.

\section{Significance of the study}

This research aimed to assesses the effect of mentoring on personnel retention in military academies. Thus, key stakeholders may benefit. The study may help as a source of reference and stepping stone for those researchers who need to make further study on the area afterward. It may also contribute for the existing knowledge about the effect of mentoring and fills the gap of theoretical and empirical evidence in the country. This study will provide empirical information to the commandants of military academies as well as human resource leaders about the mentoring effect and employee retention. This may consistently help the military units in formulating appropriate mentoring policies, making informed decisions and adopting strategies that will enhance career mentoring, psychological mentoring, role modeling and personnel retention. In turn save unnecessary expenditure and avert the loss of human capital. This may benefit the country in the provision of developing and retaining military professionals by ensuring mentoring practice in the institutions. The study provides the researcher the opportunity to gain deep knowledge on the effect of mentoring on military personnel retention. It will enhance the practical knowledge of the researcher through creating a link between the theoretical knowledge and what is going on real life in the academies. Lastly the result of the study will provide insights and information on the effect of mentoring on retention.

\section{Limitations of the Study}

This study helps to recognize the effect of mentoring on personnel retention in military academies in Ethiopia. Therefore, there are limitations on this study which require further examination and additional research in the future. The limitation of this study is that, it was carried out in military academies on protégée. Hence, this may limit the ability of the research to generalize the findings for other organizations. Finally, this study mainly employed quantitative methods and may thus suffer from the shortcomings of such a method. Possibly a combination of both quantitative and qualitative methods could provide greater insights and provide different outcomes.

\section{Operational Definitions of terms}

The terms used in the research are defined according to the current study context. Career mentoring: it is career supports help the protégés enhance their career success, and include exposure and visibility, coaching, protection and challenging assignments (Bette, 2012).

Commandant: it is the chief officer in charge of military organization (Ethiopian Army Human resource Field Manual (2011).
Mentoring: is refers to a term generally used to describe the relationship between less experienced personnel, called protégé, and the more experienced officer known as a mentor (Gina 2012).

Military Academy: is a collage or training center for training military officers (Ethiopian Army Company Field Manual 2011).

Personnel: is a military person who works in the military (Ethiopian Army regiment Field Manual 2011).

Personnel retention: it indicates a military personnel intention to stay in the military profession Ethiopian Army Human resource Field Manual 2011).

Protégée: It refers to a military person who is guided and supported by a more experienced military officer or mentor (Rhay et al. 2010).

Psychological mentoring: it is the psychosocial supports serve to increase the protégés sense of competence, identity and work-role effectiveness, including acceptance, affirmation, counseling and friendship (Lee \& Kim, 2011).

Role modeling: it refers to serving as a role modeling of appropriate attitudes, values and behaviors for the protégés (Burk \& Eby, 2010)

\section{Organization of the Study}

The rest of the chapters are organized as follows: Chapter two encompasses the review of related literature. Chapter three consists of research methodologies and Chapter four deals with results and discussions are included. Finally, chapter five presents summery, conclusions, and recommendations.

\section{Literature Review}

Chapter two reviews literature that is relevant in this research. The chapter also explores and gives more meaning to the theoretical foundations as well as empirical issues underpinning the phenomena being studied. Specifically, it is organized under three main sub-topics; theoretical review of mentoring, empirical review and conceptual frame work of the study.

\section{Definition and concepts of mentoring}

Mentoring involves the development of a junior and inexperienced persons career development, the providing of psychological support to and role modeling the junior. It is also a key element of leadership development and employee retention.

Mentoring originated back in Greek times, during the reign of Homers the Odyssey. King Odysseus, before leaving to fight in the Trojan War (a ten-year battle), entrusted his older friend mentor to teach and counsel his son, Telemachus (Bloomberg, 2014). Here the word mentor used in the meaning that refers to a person who was interested to teach the king son and it was in this way that the use of this word comes to practice.

There are various definitions that have attempted to clarify the concept of mentoring. According to Haggard et al. (2011), mentoring is an interpersonal exchange between a senior experienced person (mentor) and a less experienced junior person (protégé) in which the mentor provides support, direction, and feedback regarding career plans and personal development and frequent interaction between the mentor and the protégé with a goal of enhancing the protégés commitment and aiding in career advancement and retention.

Robin and Timothy, (2015) found that no single definition of mentoring applies to all settings, but that every discipline employs unique terms to describe this helping developmental process within its own field. According to them mentoring is a dyadic relationship in which an older, more experienced member of the organization fosters the growth and development of a junior employee to a point where he or she becomes a competent professional. On the other hand mentoring is also viewed as a dynamic, developmental relationship between two individuals based on trust and reciprocity, leading toward the enhancement of the junior members psychological commitment growth 
and career advancement and toward achieving mutual benefits for the mentor, mentee and organization.

The researcher will adopt the definition of mentoring provided by Leavitt (2011) which defines mentoring as developmental and interpersonal relationship occurring between a more knowledgeable and experienced individual (mentor) acting as a teacher, counselor and Role modeling of a less experienced or knowledgeable individual (protégé), sharing advice, knowledge, psychological support and guidance and offering support and challenge in behalf of the protégés personal and professional development.

Benefits of mentoring: Dawley et al. (2010) mentioned that mentoring refers to the mutually interdependent, empathic, and empowering processes that create personal growth, development, and enrich organizations, mentors and protégés commitment and retention. The collaborative nature of mentoring develops individuals and interpersonal links between individuals, which increases engagement and help employees develop new skills and feel engaged within the organization. These functions all lead to happier employees and a better retention rate for a stronger and more effective organization.

Benefit to the organization: Mentoring benefits to the organization are mostly related to the development of human capital and retention. Mentoring helps employees to share knowledge and experience, to get them motivated and enhance job performance and retention rates. In addition, it enhances organizational commitment (CIPD, 2012). This is achieved by providing a structured system to strengthen and affirm the continuity of the organizational culture. Organizational culture provides members with a common value base, with implicit knowledge of what can be expected of them and what they can in turn expect from the organization.

Benefit to the mentee: Mentoring function through initiation and socialization has a number of positive effects on protégés performance and retention. Mentoring functions are positively associated with compensation, number of promotions, career satisfaction, expectation for advancement, career commitment, high level of job satisfaction and low turnover intention (Chester et al., 2013)

Benefit to mentor: The mentors also benefit from the mentoring relationship. Mentors in the mentoring relationship can benefit in the following areas: they attain a higher level of professional knowledge, widened collegial networks, and raised levels of job motivation, improved competence and gaining of much more psychological support. In return for the time and effort spent in providing support to protégés, they gain positive outcomes such as career rejuvenation, personal recognition, personal satisfaction, organizational reputation and an increase in knowledge and power (Sheryn \& Ye, 2011).

Forms of mentoring: According to Weinberg and Lankau, (2011), the nature of mentoring relationship is influenced by the degree of formality adopted by the mentoring program, which in turn influences the degree of formality present in the mentoring relationship and the researchers identified two forms of mentoring relationships, namely formal mentoring and informal mentoring.

Formal mentoring: Formal mentoring refers to a mentoring relationship where a third party (usually the organization) authorities an agreement between a mentor and protégé, whereby the protégé should trust the mentor to teach or counsel him/her in order for the protégé to reach his/her full potential (Jones, 2012) some features of formal mentoring programs include top management support , corporate mentoring strategy, sensible mentor and protégé selection and matching processes, comprehensive mentor and protégé orientation, clearly stated expectations and responsibilities of the mentor and protégé and established duration and contact frequency between the mentor and protégé.
Informal mentoring: Informal mentoring relationships develop spontaneously based on mutually perceived competencies and interpersonal comfort. Informal mentoring is volitional and there are no structured guidelines for directing the informal mentoring relationship.

Under informal mentoring there are little or no interventions by the organization other than an initial introduction (Germain, 2011). The major benefits of informal mentoring to protégés and mentors are being involved in the mutual selection and mutual adjustment throughout the relationship with the goals and expectations evolving over time to adapt to the specific needs of the protégé.

\section{Types of mentoring}

Even if, the literature mostly only makes a distinction between informal and formal mentoring, there are in fact five types of mentoring (Wilson, et al., 2012 and pan et al, 2011), namely:

Executive mentoring: An informal relationship is established with an executive or director (that may be retired or not). This can lead to the protégé becoming more visible in top management

Supervisor mentoring: The protégé boss (supervisor/ manager) becomes his/her mentor. This can lead to more career advancement opportunities for the protégé.

Diversity mentoring: This includes cross-cultural mentoring where a mentor and a protégé are from different culture, cross - gender mentoring where a mentor and protégé are different sexes.

Peer mentoring: The mentor and protégé are on the same level in the organization and the relationship is relatively informal and can lead to information sharing, emotional support and in some cases, to close relationship

Hierarchical mentoring: This includes mentoring from higher grade which refers to the relationship between a junior and senior in order to enhance the knowledge and experience of junior person and from a lower grade which refers to a junior mentoring a senior person on a subject about whom the junior recently gained experience.

\section{Stages of mentoring}

Ensher et al. (2010) and Wilson et al. (2012) presented that those successive stages of mentoring relationship. And defined four distinct phases of mentoring, namely initiation, cultivation, separation and redefinition.

Initiation: A period of six months to one year during which time the relationship gets started and begins to have importance for both individuals. During this stage, the mentor provides coaching; challenging work and visibility; and the protégé provides technical assistance, respect and a desire and willingness to be coached.

Cultivation: A Period of two to five years during which the number of career and psychosocial functions provided by the mentor are increased to a maximum, During this stage, both protégé and mentor become more emotionally linked.

Separation: A period of six months to two years after a change in the structure and role of the relationship (transfer, promotions) or in the emotional parts of the relationship has taken place (feelings of independence, threat, betrayal). There are limited opportunities for interaction.

Redefinition: An indefinite period during which the relationship ends and takes on a more peer-like friendship quality, the protégé develops a relationship with new mentors.

\section{Functions of mentoring}

Function of mentoring is defined as the sum of the career mentoring, psychological mentoring, and role modeling functions as perceived by mentees in the mentoring program. According to Gina (2012), mentors provide three main functions to protégés, namely: Career mentoring, psychological mentoring and role modeling

Career mentoring: According to Bette (2012), Career mentoring establishes the protégé as an independent, successful professional. Career mentoring includes sponsorship, exposure-and-visibility, coaching, protection and challenging assignments. Career mentoring 
involves task-related aspects of work and positively linked to more objective measures of success. Benefits of career mentoring include extrinsic success factors such as compensation, promotion, and career mobility. Mentors provide their mentee with career mentoring and opportunities for career development. There exists a strong link between career support activities and positive employee outcomes including affective organizational commitment, job involvement, and reduced turnover intention.

Psychosocial mentoring: Lee and Kim, (2011) on their study mentioned that psychosocial mentoring addresses those aspects of the relationship that enhance an individuals sense of competence, identity, and effectiveness in a professional role. The benefits associated with psychosocial mentoring include affective outcomes such as affective organizational commitment or job involvement and lower turnover. Psychosocial mentoring includes intrinsic functions such as acceptance, counseling, and friendship because mentors provide their protégés with psychosocial support and opportunities for development; they contribute to the general satisfaction of protégés above and beyond the extrinsic rewards they can secure for their protégés.

Shim and Rohrbaugh, (2011) stressed that the functions of psychosocial mentoring represent a deeper, more intense mentoring relationship and often depend more on relationship quality than on career function. Psychosocial mentoring may enhance an individuals ability and effectiveness, help alleviate work-related stress, evolve into a strong emotional bond between the mentor and the protégé, and become a positive, gratifying interpersonal contact.

\section{Role modeling}

Role modeling is serving as a role model of appropriate attitudes, values and behaviors for the protégés. Role modeling consists of the mentor demonstrating appropriate behavior and knowledge, thus earning greater respect and admiration. According to Burk and Eby, (2010), the mentor demonstrates valued behavior, attitudes and skills that aid the mentee in achieving competence, confidence and a professional identity. The mentors values, attitudes and behaviors provide an example for the mentee, who in turn identifies with the mentors desirable example and in turn respects and admires his/her mentor. In terms of the organizational context, the mentor leads by example.

Personnel retention: According to Ethiopian Army Human resource Field Manual (2011), personnel retention is retain and developing military personnel to obtain a competitive advantage. Retention of personnel is critically important in military units. Furthermore, Ethiopian Army Regiment field Manual (2010) stated that the major reasons why military personnel retention is important is due to the numerous negative outcomes that are associated with turnover. The outcomes include high direct and indirect financial costs; a decrease in combat readiness and sustainability, a decrease in efficiency; the rendering of service and standards; interruption in duty flow; loss of experience and expert knowledge; an increase in administrative processes; a decline in the unit image; an interruption in the internal and informal social liaison and communication channels and an increased feeling of job dissatisfaction among the remaining personnel.

\section{Empirical findings}

The effect of career mentoring on retention: Sheryn and Ye, (2011) conducted a study on effects of mentoring programs on new teacher Retention in the University of North Carolina USA and concludes that career support can significantly affect individual retention and careers development. With both the mentor and the person being mentored (mentee) benefiting from the relationship.

On the other hand that mentoring can be beneficial to the careers of the mentor and the protégé while assisting the organization to achieve its mission.
Alethea and Ridwanah, (2013) Conducted study on researching the effect of student mentoring in University of Central Lancashire UK. The research explored the effect of career support function on student and the findings highlighted that career support has a significant effect on the mentee regarding enhancing confidence, self-esteem, skill development and engagement in pro-social behavior. Furthermore, the study concludes that career support is powerful tool to develop mentees knowledge and to retain for longer period of time in the organization.

According to McGarry (2011), a study conducted on Strategic success on mentoring and army succession planning on Canadian forces. The finding conclude that career support brings significant benefits to all those involved in the mentoring relationship, including the organization. The mentee gains knowledge and wisdom about the organization, learns faster, has increased self-confidence, increased career motivation and retention. Career support, contributes to mentee professional development and has the chance to inspire and encourage the growth of the mentee.

Cheng et al. (2014) conducted the research on the effect of mentoring functions in connection with formal mentoring in Chinese military. The result of the study indicated that career support benefits protégés by promoting positive work attitudes and career success; furthermore, the results of the study showed that the amount of formal mentoring provided is related positively to protégés affective commitment levels and associated negatively with turnover intentions.

Chan, et al. (2012) conducted the study on employee satisfaction and its effects toward loyalty in hotel industry in Malaysia. The result of the study indicated that Career support can provide opportunity to employee gain experience and trains employee on countless skills. Therefore, career support can increase in employee chances for advancement, employee retention and can lead to a more effective organization. This indicated that career support is a most important determinant of employee retention.

Mehta et al. (2010) conducted the study on employee Loyalty towards organization: a study of Academician in Nigeria. The result of the study indicated that the best way to serve employee is through career support programs and it can help increase in employees job satisfaction and feelings of empowerment in their customer-facing roles. Besides, it also can reduce employee turnover and increasing retention, loyalty, and profitability.

Carver et al. (2013) conducted a study on the role of mentorship in the Retention of graduate Interns in South Africa and conclude that mentoring relationships operate through a dual pathway to affect organizational retention by assisting in the career support while simultaneously developing the high-quality interpersonal relationships that strengthen a protégés commitment to an organization. Mentoring has beneficial effects on protégés job satisfaction, compensation, number of promotions, and intent to remain with an organization.

The effect of psychological mentoring on retention: Craig et al. (2012) conducted a study on impact of career mentoring and psychosocial mentoring on affective organizational commitment, job involvement, and turnover intention in USA. The results indicated that psychosocial support had a stronger negative relationship with turnover intention than did career support. This probably is because of the emotional, relational, counseling, and problem-solving aspects of successful psychosocial mentoring.

Jae et al. (2012) in their meta-analysis from USA, Japan and Korea comparing mentored and non-mentored individuals found that mentored individuals reported greater career satisfaction, organizational commitment, and expectations for advancement. Protégés who received higher levels of psychological support reported similar results as well as stronger intentions to remain with their 
organizations and indicated greater self-esteem and lower work stress and work-family conflict than no protégés.

Venu (2014) conducted a study on the influence of career and psychosocial support on organizational commitment and employee retention in India. The study focused on the relationships between career and psychosocial functions, the organizational commitment and employee turnover.

A survey based methodology was used and the samples were 120 IT employees. The researcher found that psychosocial mentoring had a stronger negative effect with employee turnover than did career mentoring. This probably is because of the emotional, relational, counseling, and problem-solving aspects of successful psychosocial mentoring.

Angela (2013) conducted research on the relationship between mentoring functions, job satisfaction and the retention of special education teachers Georgia. The researcher adapted survey research method and stratified sampling technique. The finding indicated that psychological support positively affects job satisfaction and retention of teachers. Furthermore it provides mentees to meet and share ideas with colleagues that can affect the intent to remain in the profession.

The effect of Role modeling on retention: Weng et al. (2010) conducted a study on exploring the effect of mentoring functions on job satisfaction and organizational commitment of new nurses in Taiwan. Results explored that role modeling functions have positive effects on the job satisfaction and organizational commitment of new nurses. This implies that if the employee is committed to the organization will stay for long period of time.

Ayse et al. (2013) in their research on effect of mentoring on organizational commitment and job satisfaction of accounting finance academicians employed in turkey. The result confirmed that role modeling had a positive and statistically significant effect on organizational commitment and job satisfaction of employee.

Chun et al. (2012) conducted a study on mentor and protégé outcomes in formal mentoring relationships in Korea. The result indicated that the role-modeling function promote perfect influence behavior on mentee through exemplary values and achievements of the mentor, own beliefs and principles, displaying self-sacrifice, and specifying the importance of having a strong sense of purpose. Furthermore the result indicated that role-modeling functions can positively influence retention and bolstering confidence of protégés to speak freely without fear of making mistakes.

Sekhosana (2011) conducted study on mentoring functions and workrelated outcomes in a steel manufacturing industry in South Africa. The finding revealed that role-modeling has positive, statistical and significant effect on job satisfaction and affective commitment. However, role-model has a negative effect to employee turnover.

Effect of mentoring on personnel retention: Hall et al (2009) conducted a study on mentoring and turnover intentions in public accounting firms in Australia and the finding reveled that mentoring generally leads to reduced turnover intentions by providing career mentoring, psychological mentoring and role modeling. Furthermore, Wasim (2013) conducted a study on impact of mentoring on employee retention in service sector Pakistan and the finding stated that mentoring has a positive impact on employee retention. On the other hand, Azman et al. (2009) conducted a study on Mentoring program and its impact on individuals advancement in Malaysian and the results have empirically confirmed that properly implemented mentoring programs can lead to increased individuals advancement and retention in the studied organization. From the above findings it implies that mentoring has an effect on employee advancement and retention.

\section{Conceptual framework of the study}

Conceptual frameworks of the study have three independent variables which are (career mentoring, psychological mentoring and role modeling) and one dependent variable (personnel retention).

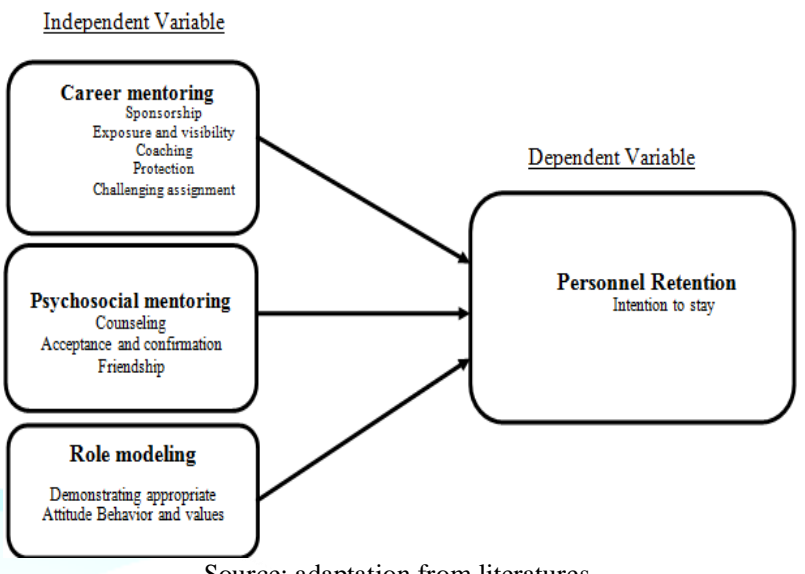

Source: adaptation from literatures.

Figure 1: Conceptual framework illustrating the effect of mentoring on personnel retention.

According to Edwin and Keith, (2014), mentors can serve three general types of mentoring functions: career mentoring, psychosocial mentoring and role modeling. Career supports help the protégés enhance their career success, and include exposure and visibility, coaching, protection and challenging assignments. Psychosocial supports serve to increase the protégés sense of competence, identity and work-role effectiveness, including acceptance, affirmation, counseling and friendship. Role modeling includes serving as a role modeling of appropriate attitudes, values and behaviors for the protégés. The dependent variable for this study was personnel retention. It indicates a military personnel intention to stay in the military profession.

Jane (2013) stated that retention is to keep that personnel who will help the military units, remain competitive to competitors on other hand, when military personnel leave, the organization will loss various things. The turnover is high so the cost of turnover (including hiring costs, training costs and efficiency loss) is high, when the military personnel leave, valuable knowledge about the military unit, current and past experience will go with him, military units must pay much time and resource has been spent on the employee in expectation of a future return.

The loss of knowledge through voluntary turnover can negatively affect military unit and growth; thus, retention of military personnel has become more important to safeguard the country from external threat. Thus the above conceptual frame works depict that mentoring provides an encouraging environment through ongoing interactions, coaching, counseling, psychological support and role modeling that facilitates progression within the military units. Therefore it has been found to influence employee retention because it helps establish an organizational culture that is attractive to the top talent demanding for growth opportunities and it is a tangible way to show military personals they are valued and that the military units future includes them.

\section{Research Methodology}

The primary focus of this chapter is to provide an overview of the research methodology used to answer the research problems. Hence, the research design, sources of data, population, sampling techniques and sample, data collection methods, reliability and validity, data 
processing and data analysis and ethical consideration of confidentiality were discussed here as follows.

\section{Research Design}

The aim of the study was to assess the effect of mentoring on personnel retention in military academies in Ethiopia. In order to address the research hypotheses and to achieve the objectives of this research, a quantitative research approach was adopted and the study followed descriptive and explanatory research design. The major purpose of descriptive research is to describe the state of affairs, as it exists at present or it helps to describe the characteristics of a phenomenon. According to Zikmund et al. (2010), the major purpose of descriptive research is to describe characteristics of objects, people, groups, organizations, or environments. And Explanatory design used to determine and explain the relationship and effect between the independent variables and dependent variable. According to Saunders, Lewis and Thornhill (2009), explanatory research is about studying a situation or a problem in order to explain the relationships between variables.

\section{Source of Data}

In order to, achieve the objective of this study, relevant data were collected from both primary and secondary sources. The primary sources include protégées of the military academies in Ethiopia and secondary data source were articles, journals and thesis related to the study. So as to develop conceptual frame work the researcher used secondary data sources.

\section{Population, sampling techniques and sample size}

The research was conducted to assess the effect of mentoring on personnel retention in the military academies. The total population of the study was 200 protégés that the study focused on. The researcher used the sample size determination table developed by Israel, (2013), the appropriate sample size for population of $\mathrm{N}=200$ mentees $\mathrm{n}=134$ and confidence level is $=0.05$. Proportionate stratified random sampling technique used in order to give proportional representation to all selected academies, which form the sampling frame of the study.

The strata for this research consist of three (3) military academies. According to Zikmund et al. (2010), stratified sampling reduces random sampling errors, groups adequately represented when strata are combined and sample ensures that the sample accurately reflect the population. The total sample size of each stratum is shown with their respective population of the following academies.

\begin{tabular}{|c|c|c|c|}
\hline Organization & Protégés & Population & $\begin{array}{c}\text { Sample } \\
\text { size }\end{array}$ \\
\hline \multirow{4}{*}{$\begin{array}{c}\text { Major General } \\
\text { Hayelom } \\
\text { Araya } \\
\text { Academy } \\
\end{array}$} & First company & 90 & 60 \\
\hline & Second company & 40 & 27 \\
\hline & Staff officers & 35 & 23 \\
\hline & Total & 165 & 110 \\
\hline \multirow{3}{*}{$\begin{array}{c}\text { Defense } \\
\text { Command and } \\
\text { Staff Collage }\end{array}$} & First company & 15 & 10 \\
\hline & Second company & 20 & 14 \\
\hline & Total & 35 & 24 \\
\hline \multicolumn{2}{|l|}{ Total } & 200 & \\
\hline
\end{tabular}

Table 1: Sample size description.

\section{Data Collection methods}

To achieve the objective of this study primary data were collected. In order to collect primary data questionnaire was used. Since the approach of the research was quantitative, the data used were collected through structured close ended and open ended questionnaire and rated on a likert scale of 1 (strongly disagree) to 5 (strongly agree). Questionnaire is simple and quick to administer and it helps to collect data from the respondents (Zikmund et al., 2010).

\section{Reliability and validity}

Reliability: Reliability is one of the major criteria for evaluating research instruments. According to Lombard (2010), Coefficients of .90 or greater are nearly always acceptable, .80 or greater is acceptable in most situations, and .70 may be appropriate in some exploratory studies for some indices. The researchers in order, to measure mentoring effect, 16 questions were adapted from (Christopher et al., 2012; Hu et al., 2011 \& Ayse et al., 2013). In addition, Employee retention 5 questions were adapted from Jane (2013). The instruments were continuously tested by different researchers and their reliability test is above 0.90. Furthermore, the researcher modified the adopted instruments to make them suitable to assess the effect of mentoring in Ethiopian military context and reexamined the reliability. Therefore, as shown in table 2 the reliability of the whole items is 0.90 which means the whole items were reliable and acceptable because as Lombard stated coefficients of 0.9 or greater are nearly always acceptable.

\begin{tabular}{|c|c|c|}
\hline Dimensions & $\begin{array}{c}\text { Previous } \\
\text { Cronbachs } \boldsymbol{\alpha}\end{array}$ & $\begin{array}{c}\text { Reexamined } \\
\text { Cronbachs } \boldsymbol{\alpha}\end{array}$ \\
\hline Career mentoring & 0.95 & 0.9 \\
\hline Psychological mentoring & 0.96 & 0.94 \\
\hline Role modeling & 0.92 & 0.9 \\
\hline Personnel Retention & 0.93 & 0.91 \\
\hline Total & 0.94 & 0.91 \\
\hline
\end{tabular}

Source: Primary data

Table 2: Previous and current reliability test.

The result from above table indicated that the items are reliable and consistent to measure the effect of mentoring on military personnel retention in the military academies.

Validity: Validity on the other hand, can be described as the extent to which the instrument measures what it purports to measure. According to Faux (2010), validity determines whether the research truly measures that which it was intended to measure. Thus validity measures how truthful the research results are or the extent to which scores truly reflect the underlying variable of interest. The instruments that the researcher used were continuously checked for the content and face validity by the researchers who have conducted researches concerning mentoring questionnaire by (Christopher et al., 2012; Hu et al., 2011 \& Ayse et al., 2013) and retention questionnaire by Jane (2013). After the modification, the questionnaire was given to supervisors and experts to ensure refinement and content validity.

\section{Data Analysis Methods}

The collected data were checked for completeness, edited, transcribing the coded data from questionnaire in to computer and coded in to the statistical package for social science (SPSS) version 20. And then Descriptive and inferential statistics were applied.

Descriptive statistics like frequency, percentage and ratio which includes the means and standard deviation were used to analyze the demographic characteristics of the respondents and the response variation of the study.

The researcher used the Pearson correlation coefficient to measure the degree of relationship between independent and dependent variables. In this research, all the independent variables (career mentoring, psychological mentoring and role modeling) and dependent variable (personnel retention) were correlated. Thus, the researcher was used Pearson Correlation analysis to measure the relationship of independent variable and dependent variable. According to Sekaran and Bougie, (2010), a correlation coefficient, $r$, is a number between -1 and +1 that used to measure the degree of relationship between in dependent variable and dependent variable.

The higher value of the correlation coefficient, the stronger the level of relationship between two variables. A positive value for the correlation coefficient indicates a positive relationship. Therefore, a negative value for the correlation coefficient indicates a negative relationship. 
The researcher used multiple regression analysis to assess the effect of the independent variable on dependent variables.

\section{Model specification}

Multiple regressions were calculated using the proposed formula to study the effect of independent variables (career mentoring, psychological mentoring and role modeling) and dependent variable (retention). Since there are three independent variables in this study the multiple regression model was as follows:

$$
\begin{aligned}
& \mathrm{Y}=\beta_{0}+\beta_{1} \mathrm{X}_{1}+\beta_{2} \mathrm{X}_{2}+\beta_{3 \mathrm{X} 3}+\varepsilon_{\text {where: }} \\
& \mathrm{Y}=\text { represents the dependent variable, personnel retention, } \\
& \beta_{0}=\text { constant } \\
& \mathrm{X}_{1}=\text { represents career mentoring } \\
& \mathrm{X}_{2}=\text { represents psychological mentoring } \\
& \mathrm{X}_{3}=\text { represents Role model } \\
& \mathcal{E}=\text { an error term, normally distributed of mean } 0 \text { (usually e is } \\
& \text { assumed to be } 0 \text { ) } \\
& \beta_{1 \ldots} \beta_{3} \text { are regression coefficients }
\end{aligned}
$$

\section{Ethical consideration of confidentiality}

The researcher addressed ethical consideration of confidentiality and privacy. The researcher used a careful and conscious effort at all times to sustain this promise. The researcher promised to all those who selected as respondents that their names should not be revealed in the questionnaire and analysis of data. In order to ensure the involvement of the respondents to give their responses genuinely with interest they have been provided a verbal and written description of the study and they were willing to participate in the study and all participants responses were confidential. All assistance, collaboration of others and sources from which information was drawn is acknowledged. Finally, the researcher will give a copy of the final report to the military academies.

\section{Results and Discussions Introduction}

This chapter presents the result of the study based on the findings using descriptive and inferential statistics. The results are presented in the form of tables and pie chart. It starts with the response rate, personal characteristics of the sample, and provides findings according to the objectives of study:

\section{Response Rates}

One hundred and thirty four respondents were selected out of the total target population of 200 for the survey and hence the same numbers of questionnaires were distributed. However, 124 questionnaires were returned and out of those 10 questionnaires were poorly filled and also 9 questionnaires were not given back thus in all a total number of 115 questionnaires were used and this represents $92.5 \%$. The response rate of $92.5 \%$ was thought adequate for both the analysis and interpretation of the data and hence used in that regard.

\section{Respondent Demographic Profile}

Educational back ground of the respondents: Details about the education levels of respondents were obtained as presented in the figure below.

Table 3 revels that those respondents who have got first degree were $59.1 \%$ and those who were the holders of college diploma and second degree were $20.9 \%$ and $16.3 \%$ respectively and the remaining $3.5 \%$ were medical doctors.

Data on Service period of respondents: The respondents years of service were deemed important to evaluate the level of experience the respondents have in the military academies. Details from the survey are given as shown on the table below.

\begin{tabular}{|c|c|c|}
\hline & Frequency & Percent \\
\hline Diploma & 24 & 20.9 \\
\hline First Degree & 68 & 59.1 \\
\hline Master Degree & 19 & 16.5 \\
\hline Medical doctor & 4 & 3.5 \\
\hline Total & 115 & 100 \\
\hline
\end{tabular}

Source: based on Primary data of this study.

Table 3: Educational back ground of the respondents.

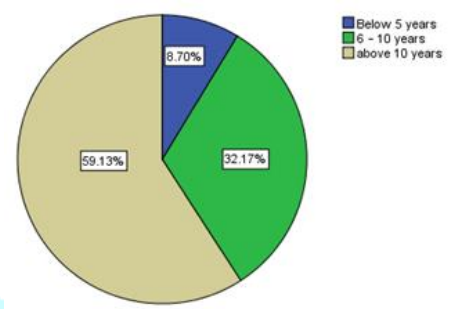

Source: based on Primary data of this study

Figure 2: Service period of respondents.

According to the above figure 2 it is evident that majority of the respondents have served in the military above 10 years were $59.1 \%$ and those who have served in the military between $6-10$ years at $32.2 \%$.

Rank description of the respondents: The study sought and obtained details about the rank held by the respondents in the academies for purposes of understanding their role in the variables of study. Details of the respondents and their ranks are shown in below

\begin{tabular}{|c|c|c|}
\hline & Frequency & Percent \\
\hline Private Soldier & 10 & 8.7 \\
\hline Noncommissioned officer & 75 & 65.2 \\
\hline Line officer & 30 & 26.1 \\
\hline Total & 115 & 100 \\
\hline
\end{tabular}

Source: based on Primary data of this study.

Table 4: Rank held by the respondents.

The analysis results from the table indicated that majority of respondents in this study were Noncommissioned officers (75), followed by line officers (30) and private soldiers (10). These represent $65.2 \%, 26.1$ and $8.7 \%$ respectively. From the above description, it can be revealed that the majority of the respondents in this study are those directly responsible for or directly involved in the implementation of mentoring System.

Duration of mentoring relationship: The respondents length of mentoring relation was believed vital to assess the effect of mentoring effect on the respondents and in the military academies. Results from the respondents are shown on the table below.

\begin{tabular}{|c|c|c|}
\hline & Frequency & Percent \\
\hline Below 5 years & 10 & $8.70 \%$ \\
\hline 5-9 years & 65 & $32.20 \%$ \\
\hline Above 10 years & 5 & $68 \%$ \\
\hline Total & 115 & 100 \\
\hline
\end{tabular}

Source: based on Primary data of this study.

Table 5: Duration of mentoring relationship.

According to the above table, majority of the respondents $68 \%$ have been mentored in the military academies above 10 years and those who have been mentored for between 5-9 years and $32.2 \%$, below 5 years $8.7 \%$ respectively. 
Descriptive Statistics

\begin{tabular}{|c|c|c|c|c|c|}
\hline & $\mathrm{N}$ & $\begin{array}{c}\text { Minimu } \\
\mathrm{m}\end{array}$ & $\begin{array}{c}\text { Maximu } \\
\mathrm{m}\end{array}$ & Mean & $\begin{array}{c}\text { Std. } \\
\text { Deviation }\end{array}$ \\
\hline $\begin{array}{c}\text { Career } \\
\text { mentoring }\end{array}$ & 115 & 1.17 & 5 & 3.029 & 0.74151 \\
\hline $\begin{array}{c}\text { Psychologica } \\
\text { 1 mentoring }\end{array}$ & 115 & 1.2 & 5 & 3.182 & 0.86148 \\
\hline $\begin{array}{c}\text { Role } \\
\text { modeling }\end{array}$ & 115 & 1.4 & 5 & 3.32 & 1.1254 \\
\hline $\begin{array}{c}\text { Personnel } \\
\text { Retention }\end{array}$ & 115 & 1.25 & 5 & 3.560 & 1.24411 \\
\hline $\begin{array}{c}\text { Valid N } \\
\text { (listwise) }\end{array}$ & 115 & & & \\
\hline \multicolumn{5}{|c|}{ Source: based on Primary data of this study. }
\end{tabular}

Table 6: Descriptive statistics of independent and dependent variables. Based on the above table, the mean and standard deviation for each of the predictor variables are as follows: Career support $(\mu=3.02,=0.74)$, Psychological support $(\mu=3.9,=0.86)$, and Role model $(\mu=3.3,=1.12)$. Besides, the criterion variable (Military personnel Retention) demonstrates a mean of 3.56 and a standard deviation of 1.24 .

\section{Inferential Analyses}

The inferential analyses include the Pearson coefficient correlation and multiple regression analysis to show the relation and effect of independent variables on dependent variable as shown below.

Pearson Coefficient Correlation: The researcher used Pearson coefficient correlation analysis to examine the degree of relationship between two variables. Mentoring and dependent variable (Personnel Retention).

Relationship between mentoring and personnel retention:

Hypothesis 1 H0: Mentoring does not correlate with retention in Ethiopia Military academies

Pearson correlation analysis was applied to assess whether mentoring in the academies related with personnel retention. The result of the study revealed that mentoring is positively correlated with personnel retention. Table 6 , describes that mentoring was positively and significantly related to personnel retention $(r=0.746, p<0.001)$ at 0.01 significance level. Therefore $\mathrm{H} 0$ was rejected since a positive significant relationship exists. This implies that better participation in mentoring leads to higher personnel retention in military academies.

\begin{tabular}{|c|c|c|c|}
\hline & & Mentoring & $\begin{array}{l}\text { Personnel } \\
\text { retention }\end{array}$ \\
\hline \multirow[t]{4}{*}{ Mentoring } & Pearson Correlation & 1 & \\
\hline & Sig. (2-tailed) & & \\
\hline & $\mathrm{N}$ & 115 & \\
\hline & Pearson Correlation & $0.746^{* * *}$ & 1 \\
\hline \multirow{2}{*}{$\begin{array}{l}\text { Personnel } \\
\text { retention }\end{array}$} & Sig. (2-tailed) & 0 & \\
\hline & $\mathrm{N}$ & 115 & 115 \\
\hline
\end{tabular}

Source: based on Primary data of this study.

Table 7: correlation of mentoring and personnel retention.

Correlation between independent variables and personnel retention: The researcher tests whether there is any relationship between independent variables and personnel retention and table 7 shows that there is a significant positive relationship between independent variables and personnel retention. Specifically, there is significant positive correlation between career mentoring and personnel retention $(r=0.582, p<0.001)$. Moreover, there is a strong significant positive correlation between psychological mentoring and personnel retention $(r=0.611, p<0.001)$. Similarly role modeling and personnel retention are significantly positively correlated $(r=0.579, \mathrm{p}<0.001)$. Lastly, the table shows strong significant positive relationship between mentoring and personnel retention.

\begin{tabular}{|c|c|c|c|c|c|}
\hline & & $\begin{array}{l}\text { Career } \\
\text { mentoring }\end{array}$ & $\begin{array}{l}\text { Psychologi- } \\
\text { cal mentoring }\end{array}$ & $\begin{array}{l}\text { Role } \\
\text { modeling }\end{array}$ & $\begin{array}{l}\text { Personnel } \\
\text { retention }\end{array}$ \\
\hline \multirow[t]{3}{*}{$\begin{array}{l}\text { Career } \\
\text { mentoring }\end{array}$} & $\begin{array}{l}\text { Pearson } \\
\text { Correlation }\end{array}$ & 1 & & & \\
\hline & $\begin{array}{l}\text { Sig. } \\
\text { (2-tailed) }\end{array}$ & & & & \\
\hline & $\mathrm{N}$ & 115 & & & \\
\hline \multirow[t]{3}{*}{$\begin{array}{l}\text { Psychological } \\
\text { mentoring }\end{array}$} & $\begin{array}{l}\text { Pearson } \\
\text { Correlation }\end{array}$ & $0.501^{* *}$ & 1 & & \\
\hline & $\begin{array}{l}\text { Sig. } \\
\text { (2-tailed) }\end{array}$ & 0 & & & \\
\hline & $\mathrm{N}$ & 115 & 115 & & \\
\hline \multirow[t]{4}{*}{ Role modeling } & Pearson & $0.412 * *$ & $0.399 * *$ & 1 & \\
\hline & Correlation & & & & \\
\hline & $\begin{array}{l}\text { Sig. } \\
\text { (2-tailed) }\end{array}$ & 0 & 0 & & \\
\hline & $\mathrm{N}$ & 115 & 115 & 115 & \\
\hline \multirow[t]{3}{*}{$\begin{array}{l}\text { Personnel } \\
\text { retention }\end{array}$} & $\begin{array}{l}\text { Pearson } \\
\text { Correlation } \\
\end{array}$ & $0.582 * *$ & $0.611 * *$ & $0.579 * *$ & \\
\hline & $\begin{array}{l}\text { Sig. } \\
\text { (2-tailed) }\end{array}$ & 0 & 0 & 0 & \\
\hline & $\mathrm{N}$ & 115 & 115 & 115 & 115 \\
\hline
\end{tabular}

**. Correlation is significant at the 0.01 level (2-tailed).

Source: based on Primary data of this study.

Table 8: correlations between independent variables and personnel retention.

Multiple Regression Analysis: The researcher used Multiple Regression Analysis to assess the effects of mentoring (Career support, Psychological Support and Role model) and dependent variable (Personnel Retention) in military academies.

According to (Cooper \& Schindler, 2008; Zikmund et al., 2010), before a parametric test assumptions of parametric test must be adhered. In line of the assumptions preliminary analyses were performed to ensure no violation of the assumptions and the result indicates that sample size of the study was in line with $\mathrm{N}>=50+8 \times \mathrm{m}$ formula and samples were selected randomly from the population. In addition, the test result of Skewness and Kurtosis indicates the result is below 0.2 and 0.3 it shows that the data is approximately normal. Further the independent variables are not correlate highly with each other, $r$ value of all independent variables are below 0.7. Moreover, the tolerance level of variables is greater than .10 and the variance inflation factors (VIF) is less than 5.0 In this study there is no a value that is extreme for one variable and the combination are logical. Lastly, the data was transformed to factor score (See annex).

\begin{tabular}{|c|c|c|c|c|c|}
\hline Model & \multicolumn{2}{|c|}{$\begin{array}{c}\text { Unstandardized } \\
\text { Coefficients }\end{array}$} & $\begin{array}{c}\text { Standardize } \\
\mathbf{d} \\
\text { Coefficients }\end{array}$ & $\mathbf{t}$ & Sig \\
\hline & B & $\begin{array}{c}\text { Std. } \\
\text { Error }\end{array}$ & Beta & & \\
\hline (Constant) & -0.617 & 0.369 & & -1.67 & 0 \\
\hline $\begin{array}{c}\text { Career } \\
\text { mentoring }\end{array}$ & 0.462 & 0.127 & 0.336 & 3.65 & 0 \\
\hline $\begin{array}{c}\text { Psychologic } \\
\text { al } \\
\text { mentoring }\end{array}$ & 0.493 & 0.108 & 0.341 & 4.548 & 0 \\
\hline $\begin{array}{c}\text { Role } \\
\text { modeling }\end{array}$ & 0.364 & 0.079 & 0.329 & 4.618 & 0 \\
\hline
\end{tabular}

Source: based on Primary data of this study.

Table 9: Multiple Regression Analysis.

Effect of career mentoring on personnel retention in military academies: Career mentoring includes sponsorship, exposure-andvisibility, coaching, protection and challenging assignments. It provides strong link between career support activities and positive employee outcomes including affective organizational commitment and reduced turnover intention.

\section{Hypothesis 2}

H0: Career mentoring does not influence retention in Ethiopian Military academies 
Table 9, shows that liner multiple regression of career mentoring on personnel retention. And the result shows that the influence of career mentoring on personnel retention is statistically significant in the model $(\beta=0.462, p<0.05)$. According to Felicity et al. (2013), the beta value is a measure of how strong independent variable influences the dependent variable.

Therefore, the better exposure to career mentoring in the military academies, the more likely that personnel retention will be enhanced. Hence, $\mathrm{H} 0$ was rejected since there is significant and positive effect of career mentoring on personnel retention in the military academies. The result is consistent with the findings of Mehta et al. (2010); Sheryn and Ye (2011); Chan et al. (2012); and Carver et al. (2013) which found out career mentoring have a significant and positive effect on employee retention. Further, Career mentoring can provide opportunity to employee gain experience and skills. Thus, career mentoring can reduces personnel turnover intentions and increase in chances for advancement and retention.

Effect of psychological mentoring on personnel retention in military academies: Psychological mentoring includes acceptance and confirmation, counseling, and friendship. Therefore, enhances the protégés sense of competence, identity and effectiveness in his/her role and relying on an emotional bond between the mentor and protégé that enhances personnel commitment and retention.

\section{Hypothesis 3}

H0: Psychological mentoring does not influence retention in Ethiopian Military academies

Table 9 indicates that linear multiple regression of psychological mentoring on personnel retention. And the result revealed the influence of psychological mentoring on personnel retention is statistically significant in the model $(\beta=0.493, p<0.05)$. According to Samprit and Ali (2006), Beta coefficient represents marginal effects of the independent variables on dependent variable. So that, the beta value of psychological mentoring is 0.493 which indicates that better experience to psychological mentoring in the military academies the more likely that personnel retention will be improved. Therefore, $\mathrm{H} 0$ was rejected since there is significant and positive influence of psychological mentoring on personnel retention in the military academies.

The result of this study is in line with the studies conducted by Jae et al. (2012); Christopher et al. (2012); Angela (2013) and Venu (2014) which revealed that psychological mentoring had strong positive and significantly influence on protégés commitment and retention in the organization. Furthermore, psychological mentoring provides mentees to meet and share ideas with mentor that can affect the intent to remain in the profession. The reason behind this outcome is the emotional, relational, counseling, and problem-solving aspects of successful psychosocial mentoring.

Effect of role modeling on personnel retention in military academies: Role-modeling consists of the mentor demonstrating appropriate behavior and knowledge, thus earning greater respect and admiration. It offers mentee in achieving competence, confidence and a professional identity which creates a strong bond and commitment to the organization which improves personnel retention in academies.

\section{Hypothesis 4}

H0: Role modeling does not influence retention in Ethiopian Military academies

Table 9 shows liner multiple regression of role modeling on personnel retention. And the result revealed that the influence of role modeling on personnel retention is statistically significant in the model $(\beta=0.364$, $\mathrm{p}<0.05)$ According to Tazebache (2011), the beta value is a measure of how strong independent variable affect the dependent variable. So that the beta value of role modeling is 0.364 which indicates that better involvement in role modeling in the military academies the more likely that personnel retention will be enhanced. Therefore, $\mathrm{H} 0$ was rejected since there is significant and positive influence of role modeling on personnel retention in the military academies. This result is similar to Weng et al. (2010); Sekhosana (2011); Chun et al. (2012) and Ayse et al (2013) the study exposed that role modeling has positive and significant influence on employee commitment and retention.

This indicated that role modeling affect employee retention through perfect influence behavior on mentee, exemplary values and achievements of the mentor, own beliefs and principles, displaying self-sacrifice, and specifying the importance of having a strong sense of purpose.

Effect of mentoring on personnel retention: Table 10 indicates the linear regression of mentoring on personnel retention. Model was valid and statistically significant since $(\mathrm{F}(3,114)=46.997, \mathrm{p}<0.001)$. The slope of the model (the coefficient of the Constant) is negative (.-617) but the regression coefficient of the overall mentoring is positive $(\beta=0.1 .289)$ and statistically significant at $\alpha=0.05 \quad(p<0.05)$. The correlation coefficient ( $R$ value) is 0.748 . This shows there is a positive statistically significant relationship. The coefficient of determination for this regression model $\mathrm{R}$ square is 0.560 this implies that Career mentoring, psychological mentoring and role modeling jointly represent $56 \%$ predicting power and has the capacity to explain 56\% of the variations in personnel retention. Therefore, the above overall result indicates that mentoring has a positive statistically significant influence on personnel retention.

\begin{tabular}{|c|c|c|c|c|c|c|c|c|c|}
\hline Model & \multicolumn{2}{|c|}{$\begin{array}{c}\text { Unstandar } \\
\text { dized } \\
\text { Coefficient }\end{array}$} & $\begin{array}{c}\text { Standar } \\
\text { dized } \\
\text { Coefficie } \\
\text { nts }\end{array}$ & $\mathbf{T}$ & $\begin{array}{c}\mathbf{S i} \\
\mathbf{g}\end{array}$ & $\mathbf{R}$ & $\begin{array}{c}\mathbf{R} \\
\mathbf{2}\end{array}$ & $\mathbf{F}$ & $\begin{array}{c}\mathbf{S i} \\
\mathbf{g}\end{array}$ \\
\hline & $\mathbf{B}$ & $\begin{array}{c}\text { Std } \\
\mathbf{E r}\end{array}$ & Beta & & & & & & \\
\hline $\begin{array}{c}\text { (Const } \\
\text { ant) }\end{array}$ & $\begin{array}{c}-0 . \\
617\end{array}$ & $\begin{array}{c}0.36 \\
9\end{array}$ & & -1.67 & 0 & $\begin{array}{c}0.7 \\
48\end{array}$ & $\begin{array}{c}0 . \\
56\end{array}$ & $\begin{array}{c}141 . \\
421\end{array}$ & 0 \\
\hline $\begin{array}{c}\text { Mento } \\
\text { ring }\end{array}$ & $\begin{array}{c}1.28 \\
9\end{array}$ & $\begin{array}{c}0.10 \\
8\end{array}$ & 0.748 & $\begin{array}{c}11.8 \\
92\end{array}$ & 0 & & & & \\
\hline
\end{tabular}

a. Dependent Variable: Personnel retention.

Source: based on Primary data of this study.

Table 10: Multiple linear regression effect of mentoring on personnel retention.

\section{Summary}

This chapter deals with summary of findings, conclusions and recommendation. Hence, the major findings of the study were analyzed and discussed in chapter four. It gives a way to draw a conclusion. Finally, a possible recommendation is forwarded for future study.

\section{Summary of major findings}

The purpose of this research was to assess the effect of mentoring on personnel retention in military academies in Ethiopia. Therefore, according to the discussion and analysis of data presented under chapter four, the following findings were drawn.

With regard to the effects of mentoring on personnel retention in military academies the finding reveled that:

- According to the Pearson correlation analysis mentoring has positive and statistically significant relationship with personnel retention in military academies.

- Multiple linear regression analysis of the research also presented significant results:

- Career mentoring has positive and statistically significant effect on personnel retention in military academies.

- Psychological mentoring has positive and statistically significant effect on personnel retention in military academies. 
- $\quad$ Role modeling has positive and statistically significant effect on personnel retention in military academies.

- The correlation coefficient $\mathrm{R}$ shows that mentoring has strong relationship with personnel retention.

- Career mentoring, psychological mentoring, and role modeling mutually predict $56 \%$ it shows that mentoring has $56 \%$ prediction power personnel retention in the military academies.

Furthermore, psychological mentoring has the highest beta coefficient with personnel retention which is 0.493 . Secondly, it is followed by career mentoring, which is 0.462 . The lowest beta coefficient was role modeling with military personnel retention, which is 0.364 .

\section{Conclusions}

This research is conducted on the effect of mentoring on personnel retention in military academies in Ethiopia.

In terms of the research objective and hypotheses the finding revealed that

- Mentoring has a positive and statistically significant relationship with personnel retention in military academies.

- Career mentoring, psychological mentoring role modeling has positive and statistically significant influence on personnel retention in military academies.

- The finding of this research indicated that providing Career mentoring, psychological mentoring, role modeling for military personnel is positively and significantly related to higher personnel commitment and higher personnel retention.

- Moreover, in this study the result showed that psychological mentoring has higher positive and statistically significant effect than career mentoring and role modeling. The reason behind psychological mentoring is the emotional, relational, and problem-solving aspects of successful psychosocial mentoring in the military academies.

- $\quad$ Further a deeper, more intense mentoring relationship enhance an individuals ability, effectiveness, help alleviate work-related stress, evolve into a strong emotional bond between the mentor and the protégé, then become a positive satisfying interpersonal contact that contribute to the general satisfaction of protégés above and beyond the extrinsic rewards they can secure for protégés.

Indeed mentoring plays a very important role in any organization, and it is said to be the backbone of strategy implementation. In addition, it is the central in nurturing and strengthening of employee competencies, psychological readiness and personnel retention.

\section{Recommendations}

- The researcher recommends that the military academies could focus on the effects of mentoring functions which is identified in this study.

- As the findings show, the psychological mentoring has highest positive and statistically significant effect than career mentoring and role modeling, it is better to emphasize on psychological mentoring to increase the retention of military personnel.

- The study employed quantitative methods. Therefore, it is suggested that future studies should employ mixed methods i.e. both quantitative and qualitative methods in order to obtain greater insights into the effect of mentoring.

- Furthermore, this study only surveyed protégés of military academies in Ethiopia; therefore, the findings cannot be generalized to other organizations. Future researchers may collect samples from different organizations mentors and protégés and continue to test the assumptions of this research.

\section{References}

1. Alethea $\mathbf{M}$ and Ridwanah G. Researching the Impact of Student Mentoring in the Community (2013) J Social Work Human Services 1: 1-8.

2. Alexis KH and Judith MS. A concept analysis of mentoring in nursing leadership (2013) Open J Nursing 3: 389-394. http://dx.doi.org/10.4236/ojn.2013.35052

3. Angela HC. Special education teacher retention, the relationship between mentoring, job Satisfaction and the retention of special education Teachers Electronic Theses \& Dissertations (2013) Paper 863

4. Armstrong. The impact of Career Mentoring and Psychosocial Mentoring on Affective Organizational Commitment, Job Involvement, and Turnover Intention (2012) Administration Society 45: 949-973 https://doi.org/10.1177\%2F0095399712451885

5. Ayşe TÇ, Cevdet $\mathrm{K}$ and Halil İ Z. Impact of mentoring on organizational commitment and job satisfaction of accountingfinance academicians employed in Turkey (2013) J emerging market 3. DOI: $10.5195 / \mathrm{emaj} .2013 .44$

6. Azman I, Muhammad MA and Sebastian KF. Mentoring program and its impact on individuals advancement in the Malaysian context (2009) J industrial engineering and management http://dx.doi.org/10.3926/jiem..v2n3.p464-498

7. Bette M. The Effect of Mentoring on Career Satisfaction of Registered Nurses and Intent to Stay in the Nursing Profession. (2012) Volume 168278. http://dx.doi.org/10.1155/2012/168278

8. Bloomberg M. The role of mentoring (2014) Physician Executive J 88/90.

9. Brad WJ and Gene RA. Formal mentoring in USA military (2011) War College Review 63.

10. Burk HG and Eby LT. What keeps people in mentoring relations bad things happen? A field study fromproteges perspective (2010) J Vocational Behavior 77: 437-446. https://doi.org/10.1016/j.jvb.2010.05.011

11. Carla S. Effects of mentoring on job satisfaction among military academicians (2013) Int $\mathrm{j}$ knowledge, culture and change management 9: 77-136 http://dx.doi.org/10.18848/14479524/CGP/v09i08/49789

12. Carver P, Sonia $\mathrm{S}$ and Nicolene B. The role of mentorship in the retention of graduate interns (2013) Alternation Special Edition, 8 86-106.

13. Catherine NM and Mike I. Role of Mentoring Programs on the Employee Performance in public universities in Kenya (2014) Int J Academic Research in Business and Social Sciences 4: 393-412. http://dx.doi.org/10.6007/IJARBSS/v4-i8/1110

14. Chan SY, Chan YF, Khoo YM, Loh PY and Wong WJ. A study of employee satisfaction and its effect towards loyalty in hotel industry (2012) J labor economics 23.

15. Chartered Institute of Personnel and Development (2012) Factsheet: coaching and mentoring, CIPD, London. Available: http://www.cipd.co.uk/hr-resources/factsheets/coachingmentoring.aspx (Accessed 24/02/15).

16. Cheng $\mathrm{C}$, Jianqiao $\mathrm{L}$ and Peng $\mathrm{W}$. Why does formal mentoring matter? The mediating role of psychological safety and the moderating role in the Chinese context (2014) International J Human Resource Management 25: 1112-1130. https://psycnet.apa.org/doi/10.1080/09585192.2013.816861

17. Chester A, Burton LJ, Xenos S and Elgar K. Peer mentoring: Supporting successfultransition for first year undergraduate psychology students (2013) Australian J Psychology 65: 30-37. https://doi.org/10.1111/ajpy.12006

18. Chiboiwa WM, Samuel MO and Chipunza J. An Examination of Employee Retention Strategy in a Private Organisation in Zimbabwe (2010) African J Business Management 4: 21032109. 
19. Christopher AC, Myria WA, Margaret FR, Cynthia KR and Deborah JA. The impact of career mentoring and psychosocial mentoring on affective organizational commitment, job involvement, and turnover Intention (2012) Administration \& Society 45: 949-973. https://doi.org/10.1177\%2F0095399712451885

20. Chronus. Mentoring and talent development solution (2012). Source: http://knowledge.wharton.upenn.edu

21. Chun CY, Changya H, Lisa EB and Chia YL. Mentoring and protégé outcomes informal mentoring in korea (2012) Journal of Career Development 40: 408-423.

22. Collings RV and Swanson RW. The impact of peer mentoring on levels of student wellbeing, integration and retention. Springer (2014) Science + Business Media Dordrecht, High Educ 68:927-942. https://doi.org/10.1007/s10734-014-9752-y

23. Cooper D and Schindler P. Business Research Methods (International Edition) (2008) Mc- Graw-Hill Education.

24. Craig MW, Allen, Margaret FR, Cynthia K and Deborah J A. The impact of career mentoring and psychosocial mentoring on affective organizational commitment, job involvement, and turnover Intention (2012) Administration \& Society 1-25. https://doi.org/10.1177\%2F0095399712451885

25. Creswell JW. Research design: qualitative, qunatitative, and mixed methods approaches (2012) Los Angeles, London, New Delhi, and Singapore: SAGE.

26. David SL and John ZS. The effect of high-performing mentors on junior officer promotion in the us army (2014) J labor economics 32.

27. Dawley DD, Andrews MC and Bucklew NS. Enhancing the ties that bind: Mentoring as a moderator (2010) Career Developmental Int 15: 259-278. https://doi.org/10.1108/13620431011053730

28. Edwin GR and Keith DW. The Efficacy of the Adaptive Mentorship (2014) J Leadership 2: 21-26. http://dx.doi.org/10.4236/ojl.2013.22003

29. Felicity A, Eric K and David A. Effect of human resource management practices on employee retention: perspectives from the mining industry in Ghana (2013) Int Res J Arts Soc Sci 2: $30-48$

30. Ensher EA and Murphy SE. The mentoring relationship challenges scale:The impact of mentoring stage, type and gender (2010) J Vocational Behavior 79: 253-266 https://doi.org/10.1016/i.jvb.2010.11.008

31. Faux J. Pre-testing survey instruments (2010) Global Review of Accounting and Finance 1: 100-111.

32. Fleig-palmer and Michelle $\mathrm{M}$. The-impact of mentoring on retention through knowledge transfer, affective commitment, and trust. dissertations and theses from the college of business administration. (2009) http://digitalcommons.unl.edu/businessdiss/4

33. François G, Pascal P, Jorge HM and Lionel Pr. Exploring the benefits of mentoring activities for the mentor (2014) Career Development International 19: 469-490. https://doi.org/10.1108/CDI-05-2012-0056

34. Germain M-L. Formal mentoring relationships and attachment theory: Implications for Human Resource Development (2011) Human Resource Development Review 10: 123-150. https://doi.org/10.1177\%2F1534484310397019

35. Gina Reid Tinio. Outcomes of mentoring interventions for new graduate nurses (2012) (Doctor of Philosophy thesis University of Illinois at Chicago) retrieved from htpp:// www.il.edu/thesis/2011/

36. Glazerman S, Isenberg E, Dolfin S, Bleeker M, Johnson A, et al. Impacts of comprehensive teacher mentoring (2010) Retrieved March 3, 2015, from http:// ies.ed.gov/ncee/pubs/20104027/pdf/20104027

37. Haggard DL, Dougherty TW, Turban DB and Wilbanks JE. Who is a mentor? A review of evolving definitions and implications for research (2011) J Management 37: 280-304. https://doi.org/10.1177\%2F0149206310386227

38. Hair JF, Bush RP and Ortinau DJ. Marketing Research within a Changing information environment. (2nd ed.) (2002) The McGraw-Hill Companies 37: 280-304.

39. Hall M, David S. Mentoring and turnover intentions in public accounting firms (2009) Accounting, Organizations and Society 34: 695-704. https://doi.org/10.1016/j.aos.2008.11.003

40. $\mathrm{Hu} \mathrm{C}$, Pellegrini EK and Scandura TA. Measurement invariance in mentoring research: A cross-cultural examination across Taiwan and the U.S (2011) J Vocational Behavior 78: 274-282. https://doi.org/10.1016/j.jvb.2010.10.003

41. Ingrid RW. The impact of induction/mentor1ng on job satisfaction and retention of novice teachers (2012) ProQuest LLC Title 17, United States Code.

42. Israel and Glenn D. Determining sample size program evaluation and organizational development, IFAS (2013) University of Florida.

43. Jae UC, John JS and Nam Y. A longitudinal study of mentor and protégé outcomes in formal mentoring relationships (2012) J Organiz. Behav 33: 1071-1094. http://dx.doi.org/10.1002/job.1781

44. Jane MN. Determinants of academic staff retention in public universities in kenya. Available from ProQuest Dissertations and Theses database. UMI No. 3025476

45. Jones J. An Analysis of Learning Outcomes within Formal Mentoring Relationships (2012) Int J Evidence Based Coaching and Mentoring 10: 57-72.

46. Jubilee D, Katie K, Dana K, James L, Ajal P and Shannon S. Examined the relationships among mentoring functions (2014) J Career Development 41: 263-281.

47. Kenneth CR. Mentoring and Turnover Intentions in the Military. Mediating Role of Multidimensional Commitment and Moderating Role of Gender within Mentor-Protégé Dyads (2013) J U.S. Army Command and General Staff College, 10.2139 .

48. Knowles C and Parsons C. Evaluating a formalized peer mentoring program: A student Voice and impact audit (2010) Pastoral Care in Education 27: 205-218. https://doi.org/10.1080/02643940903133888

49. Leavitt C. Developing Leaders through Mentoring: A Brief Literature Review (2011)Capella University.

50. Lee $\mathbf{J}$ and Kim S. Exploring the role of social networks in affective organizational commitment: Network centrality, strength of ties, and structural holes (2011) American Review of Public Administration 41: 205-223. https://doi.org/10.1177\%2F0275074010373803

51. Lisa KP. Making a mentoring relationship work: what is required for organizational success (2011) J Appl Business Economics 12: 46-56.

52. Lombard M. Practical resources for assessing and reporting Inter-coder Reliability in Content Analysis Research Projects(2010).

53. McGarry LP. Strategic success on mentoring and army succession planning (2011) R \& D Management 35, no. 5.

54. Mehta S, Singh T, Bhakar SS and Sinha B. Employee Loyalty towards Organization-A study of Academician (2010) Int J Buss Mgt Eco Res 1: 98-108.

55. Ministry of national defense. Ethiopian military human resource field manual. Addiss Abbaba, Brana printing press (2011).

56. Ministry of national defense. Ethiopian army regiment field manual. Addiss Abbaba, Brana printing press (2011).

57. Ministry of national defense. Ethiopian army company field manual. Addiss Abbaba, Brana printing press (2010).

58. Pan W, Sun L and Chow IHS. The Impact of Supervisory Mentoring on Personal Learning and Career Outcomes: The Dual Moderating Effect of Self-Efficacy (2011) J Vocational Behavior 78: 264-273. https://doi.org/10.1016/i.jvb.2010.05.001 
59. Reio TG Jr and Segredo M. Turnover intent among middle school teachers (2013) Education Research Conference 181188 .

60. Rhay HW, Ching YH, Wen CT, Li YC, Syr EL, et al. Exploring the impact of mentoring functions on job satisfaction and organizational commitment of new staff nurses (2010) BMC Health Services Research 10: 240.

61. Robin L and Timothy AM. Women Entrepreneurs Need Mentors (2015) Int J Evidence Based Coaching Mentoring 13: 70-86.

62. Samprit Chatterjee and Ali SH. Regression Analysis by Example. (4th ed) (2006) India: John Wiley \& Sons, Inc.

63. Saunders M, Lewis P and Thornhill A. Research methods for business students. (5th ed.) (2009) Harlow FT Prentice Hall Thornhill.

64. Seema T, Tarika S, Bhakar SS and Brajesh S. Employee commitement towards organization-A study of academician (2010) Int Business Management Economic Res 1: 98-108.

65. Sekaran U and Bougie R. Research Methods for Business: A Skill Building Approach (5th ed.) (2010) Chichester,-West Sussex: John Willey \& Sons, Inc.

66. Sekhosana LW. Mentoring functions and work-related outcomes in the steel manufacturing industry (2011) Human Resource Management Review 1: 209-236.

67. Sheryn W and Ye H. Effects of Mentoring Programs on New Teacher Retention. Mentoring \& Tutoring (2011) Partnership in Learning 19: 139-156.

68. Shim DC and Rohrbaugh J. Government career commitment and the shaping of work environment perceptions (2011) American Review of Public Administration 41: 263-284. https://doi.org/10.1177\%2F0275074010374504

69. Tazebachew A. The impact of training on worker performance in public sector organizations a case of Ethiopia ministry of health.(Masters thesis, University of Addiss Abbaba) (2011) retrieved from htpp:// www.adun.edu/thesis/2011/

70. Training main department. Yearly bulletin on performance of military academies (2014) Addiss Abbeba, Brana printing press.
71. Truter I. Responsibilities of a leader as a coach and mentor (2008) SA hermetical J 75: 58-61.

72. Van Dijk HG. The talent management approach to human resource management attracting and retaining right people (2011) J public administration.4,(3.1)385.

73. Venu Arelly. The influence of career and psychosocial mentoring on affective institutional commitment, job commitment and employee turnover (2014) Engineering Management Security5: 450.

74. Viator Ralph. "An examination of African Americans access to public accounting mentors: perceived barriers and intentions to leave (2001) Accounting, Organizations and Society J 26: 541 561.

75. Vijayalaxmi R. Protégé predictors of successful mentoring: a review of current research outcomes of mentoring (2012) Int J Management Strategy 3.

76. Wasim AA. Impact of employee mentoring on retention: A case of service sector organizations in Pakistan (2013) Interdisciplinary $\mathbf{J}$ contemporary research business research 326 5.

77. Weinberg FJ and Lankau MJ. Formal Mentoring Programs: A Mentor-Centric and Longitudinal Analysis (2011) J Management 37: 1527-1557. https://doi.org/10.1177\%2F0149206309349310

78. Wilson ZS, L Holmes, K de Gravelles, MR Sylvain, L Batiste, et al. Hierarchical Mentoring: A Transformative Strategy for Improving Diversity and Retention in Undergraduate STEM Disciplines (2012) J Sci Education Tech 1: 148-156. https://doi.org/10.1007/s10956-011-9292-5

79. Zikmund WG, Babin BJ, Carr JC and Griffin M. Business Research Methods (8th ed.) (2010) New York: South- Western/ Cengage Learning. 